\title{
Ny kunnskapsbasert retningslinje om epilepsi
}

\author{
Det er nylig utarbeidet en norsk kunnskapsbasert retningslinje om utredning, behandling, rehabilitering \\ og oppfølging av pasienter med epilepsi. Målet er å heve den generelle kvaliteten og utjevne de geografiske \\ forskjellene i norsk epilepsiomsorg. Retningslinjen ligger på nettet, har god søkefunksjon og kan lastes opp
} som gratis app.

Norsk Epilepsiforbund har gjennom flere år fătt tilbakemeldinger om at det er ujevn kvalitet i norsk epilepsiomsorg. Dette inntrykket ble styrket gjennom Lossius-utvalgets rapport (1). Det er også funnet regionale forskjeller i antall sykehusinnleggelser og i poliklinisk oppfølging av barn med epilepsi $(2,3)$.

Forbundet tok derfor kontakt med Helseog omsorgsdepartementet med tanke på å utarbeide en norsk retningslinje for utredning og behandling av personer med epilepsi. Departementet tok deretter kontakt med Helsedirektoratet, som satte Spesialsykehuset for epilepsi (SSE) ved Oslo universitetssykehus til å lede arbeidet. Målsettingen har vært å bedre kvaliteten på norsk epilepsiomsorg på alle nivåer i helsevesenet samt utjevne dagens geografiske forskjeller.

Retningslinjen skulle ha gyldighet for hele pasientpopulasjonen og dekke hele forløpet. Alt fra mistanke om og utredning av epilepsi via behandling og oppfølging av både pasienter og pårørende til rehabilitering skulle inkluderes, likeledes hvordan man best kan leve med sykdommen.

Målgruppen er hele tjenesteapparatet som skal bistå personer med epilepsi, både i kommunene og i spesialisthelsetjenesten. Språklig og faglig skal den være innrettet etter dette, og vi tror den vil være til nytte også for pasienter og pårørende.

\section{Metode}

Vi har fulgt Helsedirektoratets veiledning for utarbeiding av retningslinjer og International League Against Epilepsys forslag til oppbygging $(4,5)$. Vi har søkt i nasjonale og internasjonale kvalitetssikrede retningslinjer og prosedyrer samt systematiske oversikter i Cochrane-biblioteket. Det er i tillegg gjort systematiske og usystematiske søk i utvalgte databaser etter oversiktsartikler og metaanalyser. Vi har hatt som mål å gradere kvaliteten på dokumentasjonen og styrken på anbefalingene ved hjelp av graderingssystemet GRADE (Grading of Recommendations, Assessment, Development, and Evaluation).

Våre anbefalinger er ikke juridisk bindende og er ikke ment å skulle erstatte sunt klinisk skjønn og persontilpasset medisin (6). Det oppfordres imidlertid til at man dokumenterer i pasientjournalen hvorfor man eventuelt velger å fravike dem.

Retningslinjen er utarbeidet av en bredt sammensatt arbeidsgruppe, der alle helseregioner er representert. Ved siden av nevro- loger og barneleger med særlig kompetanse i epileptologi hadde vi i gruppen også med nevrofysiolog, nevropsykolog, epilepsisykepleiere, sosionom, ergoterapeut, fysiotera-

\section{«Våre anbefalinger er ikke juridisk bin- dende og er ikke ment à skulle erstatte sunt klinisk skjønn og per- sontilpasset medisin»}

peut, ernæringsfysiolog og spesialpedagog. Brukerrepresentanter fra Norsk Epilepsiforbund har vært helt sentrale i arbeidet. Det lyktes oss ikke å få med en fastlege.

\section{Konkrete anbefalinger}

Ved siden av en kort innføring i hva epilepsi er tar retningslinjen for seg utredning, behandling, praktisk anfallshåndtering, spesielle pasientgrupper, oppfølging, pasientopplæring, rehabilitering og tilleggsutfordringer.

Bortsett fra ved farmakologisk behandling hos voksne er det i fagfeltet få gode randomiserte, kontrollerte studier. Det gjelder særlig pasientgrupper som barn, utviklingshemmede og eldre samt innenfor oppfølging og rehabilitering. Der den faglige kunnskapen har vært mangelfull, har våre anbefalinger for en stor del måttet bli basert på vår kliniske erfaring.

For pasienter som får sitt første sikre eller suspekte epileptiske anfall, anbefaler vi rask henvisning til spesialisthelsetjenesten. Her bør pasienten bli undersøkt av barnelege eller nevrolog med særlig kompetanse innen epilepsi. Som et minstekrav har vi anbefalt grundig sykehistorie med komparentopplysninger, klinisk somatisk og nevrologisk undersøkelse, standard EEG-undersøkelse og cerebral MR-undersøkelse. Videre anbefaler vi at pasienten tidlig i behandlingsforløpet får vurdert sitt habiliterings-/rehabiliteringsbehov og at det blir klarlagt om vedkommende har andre utfordringer enn anfallene.

\section{Medikamentvalg}

Der det hos voksne er indisert å starte behandling, kommer vi med konkrete medi- kamentanbefalinger for fokale epilepsier (okskarbazepin, lamotrigin eller levetiracetam) og generaliserte epilepsier (valproat). For kvinner som vil ha barn anbefales levetiracetam eller lamotrigin.

Hos barn forekommer det mange forskjellige epilepsiformer som det er viktig å ta hensyn til ved valg av behandling. Trass i svak dokumentasjon og varierende kunnskapsgrunnlag har vi gitt forslag til preparatvalg ved de forskjellige anfallsog epilepsiformene.

Ved manglende effekt av antiepileptika anbefaler vi å vurdere epilepsikirurgi tidlig i forløpet. Dersom pasienten ikke oppnår anfallskontroll etter å ha forsøkt to-tre relevante antiepileptika i tilstrekkelige doser og i lang nok tid, anbefaler vi å vurdere ikke-farmakologisk behandling, i første rekke epilepsikirurgi, subsidiært vagusnervestimulering eller ketogen diett.

Vi foreslår at alle med epilepsidiagnose i tillegg til sin fastlege får en fast kontakt i spesialisthelsetjenesten, enten i form av barnelege/nevrolog eller epilepsisykepleier. Kontakthyppigheten vil måtte individualiseres.

Kunnskapsbasert retningslinje om epilepsi finnes på våre nettsider $w w w$. epilepsibehandling.no (7) eller kan lastes opp som gratisapp via MyMedicalBooks i App-Store/Play Store.

Denne artikkelen er skrevet på vegne av arbeidsgruppen.

Karl 0. Nakken

karln@ous-hf.no

Ellen Sundland Kjendbakke

Kari Modalsli Aaberg

Karl O. Nakken (f. 1945) er overlege, dr.med. og spesialist i nevrologi. Han har spesialkompetanse innen epileptologi og er medisinsk fagsjef ved Spesialsykehuset for epilepsi (SSE). Forfatter har fylt ut ICMJE-skjemaet og oppgir følgende interessekonflikter: Han har mottatt honorar fra Eisai for foredrag og for å sitte i Advisory Board.

Ellen Sundland Kjendbakke (f. 1971) er cand.paed og undervisningsleder ved Spesialsykehuset for epilepsi (SSE).

Forfatter har fylt ut ICMJE-skjemaet og oppgir ingen interessekonflikter. 
Kari Modalsli Aaberg (f. 1973) er spesialist i barnesykdommer, overlege og stipendiat. Hun er i gang med epidemiologiske studier av barn med epilepsi.

Forfatter har fylt ut ICMJE-skjemaet og oppgir ingen interessekonflikter.

\section{Litteratur}

1. Epilepsi - mer enn anfall. Rapport vedrørende epilepsiservice i Norge. IS-1399. Oslo: Sosialog helsedirektoratet, 2006.

2. Epilepsi. Barn, medisinske innleggelser, medisinsk poliklinikk/dag, 2011-2014.

www helseatlas.no (28.11.2016).

3. Surén P, Bakken IJ, Lie KK et al. Fylkesvise forskjeller i registrert forekomst av autisme, AD/HD, epilepsi og cerebral parese i Norge. Tidsskr Nor Legeforen 2013; 133: 1929-34.

4. Veileder for utvikling av kunnskapsbaserte retningslinjer. IS-1870. Oslo: Helsedirektoratet, 2012

5. Sauro KM, Wiebe S, Perucca E et al. Developing clinical practice guidelines for epilepsy: A report from the ILAE Epilepsy Guidelines Working Group. Epilepsia 2015; 56: 1859-69

6. Persontilpasset medisin i helsetjenesten. Rapport fra nasjonal utredning 2013/2014. Hamar: Helse Sør-Øst, 2014. www.helse-sorost.no/fag/ persontilpasset-medisin-i-helsetjenesten (28.11.2016).

7. Kunnskapsbasert retningslinje om epilepsi. www.epilepsibehandling.no (29.11.2016).

Mottatt 14.11. 2016 og godkjent 29.11. 2016.

Redaktør: Ketil Slagstad.

Publisert først på nett. 